\title{
Editorial: PFI/PPP: past, present and future
}

\section{S. Wamuziri MSc, MBA, PhD, CEng, MICE, MASCE, FRSA}

Welcome to this special issue of the Management, Procurement and Law journal. The journal publishes original research and practice papers on all civil engineering and construction aspects of management, procurement and law as part of the Proceedings of the Institution of Civil Engineers. This special edition of the journal focuses on use of private-finance initiative/publicprivate partnership (PFI/PPP) approaches to delivering infrastructure projects and services.

PFI/PPP procurement has been widely used in the UK for delivery of infrastructure and public services including roads, bridges, hospitals, prisons, schools and office accommodation. There are at present over 500 operational projects in the UK procured through PFI/PPP since its introduction by the government in 1992. Over the five-year period 2006-2011, it is estimated that the total PFI/PPP deal pipeline represents around 200 projects worth over $£ 26$ billion in capital value. In March 2006, the HM Treasury report entitled PFI: Strengthening Longterm Partnerships, ${ }^{1}$ reaffirmed the UK government's commitment to PFI/PPP procurement in delivering public services where it can demonstrate value for money.

Outside the UK, private sector participation in providing financing as well as operational expertise to deliver public services has been embraced by governments in both developed and developing countries. Sectors in which increased private sector investment has taken place include telecommunications, power generation and distribution, water supply and waste water treatment. According to the World Bank, over the period 1990-2005, nearly 3200 private infrastructure projects were implemented in 139 countries and mobilised investment of some US\$964 billion.

From a UK perspective, it is now 15 years since the introduction of PFI/PPP and thus an appropriate point at which to assess past achievements of the procurement strategy and draw important lessons for the future. In relation to developing countries, relevant questions include how PFI/PPP procurement can be modified or improved further to deliver expansion of the much-needed infrastructure and social services.

In traditional procurement of infrastructure projects, the construction of publicly-owned assets such as roads or prisons is typically undertaken to detailed specifications by private contractors following competitive tender. Under PFI/PPP procurement, private sector capital is used to finance design, construction, maintenance and operation of infrastructure. Once construction is completed, the public sector is responsible for providing public services using publicly-owned infrastructure. Under the PFI/PPP model, the public sector purchases services such as the availability of prison places or office accommodation from the private sector which manages the underlying infrastructure. This affects how public services are financed but not who ultimately pays for them.

PFI/PPP procurement involves a complex series of contracts that are primarily regulatory instruments. They spell out the rights and obligations of the government and the private parties. They also help to allocate risks and cash flows to the various participants. These contractual mechanisms have important incentive effects. It can be argued that the agency effects of PFI/PPP procurement are increased production efficiency, improved incentives for production of information and increased external scrutiny of infrastructure projects. The private sector will undertake rigorous economic analysis of a project to ensure profitability. Positive results add justification to the need for facilities. A poor response from the private sector may well reflect uncertain demand.

The move by governments worldwide to increase private sector participation in infrastructure provision has redefined and redrawn the boundary between public and private sector service provision. This has important implications for incentives to invest and competition to provide services. The role of the state has changed as a result of the need to introduce innovative regulatory practices to oversee the provision of essential infrastructure services, particularly where a monopoly situation would result. As to whether tax payers obtain value for money in PFI/PPP projects, it can be argued that competition in the awarding of contracts, an effective regulatory regime where relevant, and efficient risk allocation coupled with agency effects should in principle lower the overall costs of the service to the end user.

This special edition is being published at a time when there are significant uncertainties in the money markets and the world economy. These uncertainties have led to a number of bank failures in the UK and USA; a reluctance on the part of banks to lend to each other, to corporations and to individuals. Uncertainties in the money markets have significant implications for the costs of borrowing and financing of PFI/PPP projects. The interest rates charged on commercial 
project borrowing are normally at a margin above Libor - the London inter-bank offer rate. Libor is a floating rate of interest. This is the rate at which banks lend funds to each other in the London inter-bank market. The costs of funding for projects are usually at a margin over Libor. This is normally of the order of 100 to 200 basis points. The rate is also usually adjusted as the project progresses through various stages. The margin is also normally highest during the construction stage. Under proper market conditions, Libor is generally slightly higher than central bank base rates and was at one time about 0.08 percentage points (or 8 basis points). According to The Economist of 4-8 October $2008,{ }^{2}$ to get dollar funds overnight from the European Central Bank in September 2008, banks were prepared at one time to pay interest of $11 \%$, five times the pre-crisis rate. Governments and central banks have taken steps to get banks to start lending to each other again and thus help maintain the liquidity of the financial system.

Of particular interest and relevance to the financing of infrastructure projects is the recent Financial Stability Report ${ }^{3}$ published by the Bank of England on 28 October 2008. This report (issue 24) highlights that we are going through a period of global financial instability caused by an extended global credit boom, rapid bank balance sheet expansion and creation of bank assets/loans whose liquidity and quality were uncertain. Although governments and central banks have in recent months responded by providing comprehensive and system-wide support to improve the liquidity and stability of the financial system, we are facing a global economic slowdown. The UK government and the Bank of England's recapitalisation programme for banks is helping to improve confidence in the financial system. However, there is at present a funding gap of over $£ 700$ billion between customer deposits and loans. In the past, banks would have bridged this gap using wholesale borrowing from the money markets. Although Libor rates have been slowly moving downwards in recent months, strains in the global inter-bank lending system remain. This means that unless alternative sources of finance can be found from, for example, sovereign funds, banks will need to cut lending to strengthen the quality of their balance sheets. These alternative sources of finance are available but at a cost which is much higher than before. A case in point is the recent issue of $£ 3$ billion of reserve capital instruments by a major UK bank at an annual coupon of 14\% payable until 2019. The fact that the securitisation process, which banks have exploited in the past to repackage and resell their loans to improve their balance sheets, has been discredited makes this source of longterm capital uncertain for banks and projects as well. Clearly, significant fluctuations in the Libor rate, which has been a significant feature of the money markets over the past few months, the global economic slowdown, uncertainties in the inter-bank money markets, a large funding gap between customer deposits and loans coupled with expensive alternative sources of sovereign loans for banks will clearly drive up the costs for large-scale project lending at least in the short to medium term.

In this edition, there are six papers covering water supply, ports, light rail transport, and the schools sectors. The papers provide an international perspective on use of PFI/PPP in delivering essential infrastructure. The papers are derived from case studies and research conducted on projects and services in various countries including the UK, Armenia, Uganda and Greece. This edition provides the opportunity to share experiences and knowledge with the worldwide civil engineering community on up-and-coming and current issues relating to PFI/PPP procurement. The edition is an invaluable resource to senior professionals in the industry including lenders, contractors, clients and consultants. The contributors to this edition share best practice, present leading-edge thinking, challenge current practice, offer case studies and identify new approaches.

The following paragraphs describe the papers that are included in this edition.

Aritua, Smith and Athiyo present results of research on 'building schools for the future' projects in England. ${ }^{4}$ The authors investigate the role of the private sector in delivering schools projects; why PFI/PPP schools projects in England experience complications and offer possible solutions to these problems. Using a case-study approach, they conclude that strategic change management could be managed better. The authors argue that if the strategic vision of the public sector agency is clear, then outline designs and specifications for the facility which provide the basis for private sector partners to prepare their bids will offer opportunities for the PFI consortium to innovate in design, construction and operation of the facilities. The authors contend that if the strategic vision of the BSF scheme is unclear or subject to change, this will affect the nature of the physical asset and the risk profile. Thus time and effort spent at the mobilisation stage to clarify the vision and strategic objectives from which programmes and projects result, will give synergies which are likely to lead to improved efficiency of delivery of BSF projects and fulfilment of central government policy.

Kayaga reports the results of research into use of PPPs for delivery of improved water supply and sanitation services in sub-Saharan Africa. ${ }^{5}$ PPP models for involvement of the private sector in water supply and sanitation may take the form of management contracts, leases, build-own-operateand-transfer (B00T) arrangements or outright divestiture of water supply companies. Private sector participation in water supply in sub-Saharan Africa has been advocated on the basis that it brings with it a number of distinct but complementary factors including increased efficiency in investment, management and operations, access to private finance, reduction of government expenditure and indebtedness, opportunities for capital market development and potential to stimulate foreign direct investment. Efficiency in investment and operations is derived from charging cost-covering tariffs, improved incentives for operational efficiency, access to superior management expertise and technology, and opportunities for competitive discipline or an effective regulatory regime. Private sector investment and participation in infrastructure in sub-Saharan Africa has been mainly in telecommunications, energy and the transportation sectors and less so in water supply and sanitation. In fact PPPs in water supply in sub-Saharan Africa have been mainly in the form of management contracts. The author presents a case study of Uganda's National Water and Sewerage Corporation and concludes that its performance did not improve as much as was first anticipated when it was managed twice by 
international operators under PPP management contracts. On the contrary, it made tremendous gains in efficiency under a public management improvement model. This work confirms that for PPPs to be effective in the water sector or indeed where a monopoly situation exists, careful thought ought to be given to the process of contract design and award and that an effective regulatory framework is essential. Context-specific factors are also essential and may well determine the success or otherwise of water PPPs.

Patsiadas and Angelides consider the legislative framework for private sector participation in marine infrastructure projects in Greece. ${ }^{6}$ Details of recent changes in Greek law developed within a European Union context to govern the award process, financing and contractual details for PPP projects are described. The procedures for bringing in PPP concession contracts in the case of two major port entities in Piraeus and Thessalonika are evaluated. The case for these two port concession contracts is rather unique in the sense that external private sector funding for them has been leveraged in through flotation on the Greek stock exchange. Although the Greek government is the majority shareholder in these entities, it is not the sole shareholder. These two port concessions also appear to fall outside recent changes in the Greek PPP legal framework. This legal framework will however govern the procedure for bringing in private sector participation to a further ten more ports. The authors conclude that other forms of private sector participation in port projects in Greece are possible, including the formation of joint ventures.

Wamuziri and Jiang discuss the role of export credit agencies in international PFI/PPP projects. ${ }^{7}$ These roles include lending to exporters of relevant services, lending to investors or lending directly to the PFI/PPP project company. Export credit agencies also play the role of insurers. The fundamental motivation of diversification is to reduce risk and fluctuations in earnings or profits. The authors argue that export credit agencies are diversified in country risks and therefore best placed to cover political and non-commercial risks inherent in infrastructure projects. Examples of risks that export credit agencies can cover include currency inconvertibility and transfer restrictions, government expropriation, war, civil disturbance or breach of contract. Export credit agencies also offer professional advisory services relevant to international PFI/PPP projects including arranging project finance and disputes resolution. Involvement of export credit agencies in international PFI/PPP projects provides international lenders, contractors and consultants with necessary assurances. This engagement and collaboration between export credit agencies and key international private sector participants in PFI/PPP projects offers the opportunity to increase foreign direct investment into infrastructure in developing countries.

Mugabi and Marin discuss the process and results of a water PPP management contract in Armenia. ${ }^{8}$ Prior to implementation of the contract, a chronic water shortage problem, poor pressure and lack of service to higher floors of tall buildings, poor maintenance culture resulting in excessive leakages and wastage, low cost recovery and insufficient funds to repair and improve the network are reported. Following implementation of the PPP contract, which was hybrid including elements of a concession and a lease, significant improvements in operational and financial performance were seen. The authors report improvements in the quality of the water supply services, energy efficiency, increase in numbers of customer meters installed and better collections. Furthermore, the presence of international private sector participation in the water sector in Armenia had a positive institutional development impact which brought about changes in government policy regarding water services. The major changes included adoption and enforcement of new laws and regulations specific to the water sector covering water metering, billing and revenue collection, taxation and other financial matters. This case study has important lessons for politicians and decision makers in developing countries in that for private sector participation in PPP projects or management contracts to be effective in the water sector, governments must create the necessary enabling framework.

Smith and Gannon examine the case for political support and evaluate the importance of political risk management in light rail transportation PPP projects in the UK. ${ }^{9}$ Political risk management is a subject that has been researched widely from a corporate perspective for multinational enterprises and from an international point of view for foreign direct investment into infrastructure. Based on the analysis of wide-ranging case studies and using quantitative and qualitative research methods, the authors assert that political support is important in order to get a project off the ground. To achieve this political backing, it is necessary for the sponsors to have a credible business case in the first instance. Political support is driven by the government's policies and priorities. Genuine political support enables rapid decision making and approvals. A lack of political commitment weakens the strategic framework for corporate decision making and may lead to wastage of significant funds and time in project development. Political information relevant to a project may be identified by examining the project fit with central and local government policies and priorities, financial commitment to the project and the project link with other projects that already have political support. The authors conclude that the identification and representation of political support is more important than sophisticated quantitative risk analysis techniques such as Monte Carlo simulation, particularly during the early stages of a project.

\section{REFERENCES}

1. Her Majesty's Treasury. PFI: Strengthening Long-term Partnerships. Her Majesty's Stationery Office, Norwich, 2006.

2. Anon. The credit crisis: world on the edge. The Economist, 2008, 389, No. 8600, 13-14.

3. BanK of England. Financial Stability Report. Bank of England, London, October 2008, Issue 24.

4. Aritua B., Smith N. J. and AthiYo R. Private finance for the delivery of school projects in England. Proceedings of the Institution of Civil Engineers, Management, Procurement and Law, 2008, 161, No. 4, 141-146.

5. KaYAga S. Public-private delivery of urban water services in Africa. Proceedings of the Institution of Civil Engineers, Management, Procurement and Law, 2008, 161, No. 4, 147-155.

6. Patsiadas P. and Angelides D. C. Legislative frameworks for port concessions in Greece. Proceedings of the Institution of Civil Engineers, Management, Procurement and Law, 2008, 161, No. 4, 157-162. 
7. WAMUZIRI S. and JIANG M. Role of export credit agencies in PFI/PPP projects. Proceedings of the Institution of Civil Engineers, Management, Procurement and Law, 2008, 161, No. 4, 163-169.

8. Mugabi J. and Marin P. PPP in urban water: lessons from Yerevan, Armenia. Proceedings of the Institution of Civil
Engineers, Management, Procurement and Law, 2008, 161, No. 4, 171-178.

9. Smith N. J. and Gannon M. Political risk in light rail transit PPP projects. Proceedings of the Institution of Civil Engineers, Management, Procurement and Law, 2008, 161, No. 4, 179-185.

\section{What do you think?}

To comment on this paper, please email up to 500 words to the editor at journals@ice.org.uk

Proceedings journals rely entirely on contributions sent in by civil engineers and related professionals, academics and students. Papers should be 2000-5000 words long, with adequate illustrations and references. Please visit www.thomastelford.com/journals for author guidelines and further details. 